The Southern California Political Science Association is continuing with its series of quarterly meetings begun in 1948. Meetings of the Association have recently been held at Pomona College (April 13, 1951), the University of Southern California (July 20, 1951), and Los Angeles State College (November 2,1951 ). The program of the meeting last mentioned centered upon a paper, presented by Robert G. Neumann of the University of California at Los Angeles, entitled "Are France's Moderate Parties Doomed?" Officers of the Association for the academic year 1951-52 include: Carlton C. Rodee of the University of Southern California, president; and Ivan Hinderaker of the University of California (Los Angeles), Luther J. Lee, Jr., of Pomona College and Lester H. Phillips of the University of Redlands, members of the Executive Committee.

The twentieth annual meeting of the Southern Political Science Association was held at Chattanooga, Tennessee, November 8-10, 1951. The program was approximately equally divided between southern government and politics and international relations and comparative government. "The Democratization of the German Civil Service" was the subject of the presidential address by Taylor Cole of Duke University. Edward H. Litchfield, executive director, American Political Science Association, represented that Association at the meeting and discussed the activities of its Washington office. Others to address the meeting were Paul T. David, Public Administration Service, and Albert Gore, member of Congress. The Southern Political Science Association will hold its next annual meeting at Nashville, Tennessee. Its newly elected officers include: George W. Spicer of the University of Virginia, president; Joseph M. Ray of the University of Maryland, vice-president; and Mavis Mann of the University of West Virginia, recording secretary.

The annual meeting of the Midwest Conference of Political Scientists for 1952 will be held on the campus of the University of Notre Dame on Thursday, Friday and Saturday, April 24-26. Suggestions concerning the program for this meeting should be sent to Harold M. Vinacke of the University of Cincinnati, president of the Conference, or to Royden Dangerfield of the University of Illinois, chairman of the Program Committee.

\title{
OTHER ACTIVITIES
}

The Historical Division, Office of the United States High Commissioner for Germany, is preparing some forty monographs involving aspects of HICOG operations in Germany. While some of the studies are classified, others are available in printed form without restriction. Studies in the latter category which have been published or are in press are: The Allied High Commission for Germany: Its Establishment, Structure and Procedures, by Elmer Plischke; United States Policy and Program in the Field of Religious Affairs, by Beryl R. McClaskey; The Exchange of Persons Program in Western Germany, by Henry P. Pilgert; and The Development of Information Services in Western Germany, by Henry P. Pilgert. 
Established in May, 1950, the Historical Division, has a staff of American social scientists, most of whom are on leave from American universities. Harold Zink recently returned to his position at Ohio State University after serving for fifteen months as chief historian of the Division. He has been succeeded by Roger $\mathrm{H}$. Wells of Bryn Mawr College. The professional staff includes, in addition to persons already mentioned, Hubert G. Schmidt, Guy A. Lee, Rodney Loehr, and J. F. J. Gillen. Communications regarding the Division or its publications should be addressed to the chief historian, Historical Division, Office of the Executive Secretary, HICOG, APO 80, c/o Postmaster, New York, N. Y.

The United States Department of State has deposited in the National Archives in Washington, D. C., approximately 100,000 frames of microfilms of documents of the old German Foreign Office. These microfilms cover the period from August, 1914, to November, 1918. While not presenting a complete documentation of German foreign policy during the first World War, they contain some of the principal political files and therefore offer large opportunities for research. These files are open to qualified scholars, and photostats of documents can be purchased. The Department expects that additional microfilms for the years 1914-1918 will later be released. The British Foreign Office has made a similar release of these German documents to the Public Record Office in London.

A leaflet listing Census Bureau Publications on Governments has been issued by the Bureau of the Census and is available from that agency upon request. This bulletin describes briefly each of the fourteen reports on governmental finances and employment which the Census Bureau expects to issue in the fiscal year beginning July 1, 1951, and lists other recent publications of the Bureau regarding state and local governments.

International Political Science Abstracts, a new quarterly sponsored by the International Political Science Association and the International Studies Conference, with the support of UNESCO, made its appearance in May, 1951, with a double number consisting of abstracts of some 700 articles published in 1950. It is expected that the abstracts, 100 to 200 words in length, and taken from about 60 periodicals published in all parts of the world, will in the future appear not later than three to six months after the originals. To maximize their utility to users in many countries, articles published in English will in general be abstracted in French, and articles in other languages will be abstracted in English. The journal is under the editorship of Professors Jean Meynaud, University of Paris, Saul Rose, University of Aberdeen, and Bruce Lannes Smith, Foreign Service Institute, Washington 25, D. C. Distribution will be through Presses universitaires de France and Blackwell's, Ltd., Broad Street, Oxford, England. For American subscribers, the price is $\$ 3.00$.

With the aid of a recent foundation grant, the Center for Research on World Political Institutions in the Woodrow Wilson School of Public and Inter- 
national Affairs of Princeton University has undertaken a three-year interdisciplinary study of the history of political integration. Dana G. Munro, director of the School, and Richard W. Van Wagenen, director of the Center, have announced the appointment of two historians who will be members of the group that is to be engaged in the study. The historians are Maurice DuP. Lee, formerly instructor in the department of history at Princeton, and Francis Loewenheim, who recently finished his studies for the doctorate at Columbia University.

The Institute for Social Research in Oslo, Norway, has offered a prize of 10,000 Norwegian crowns for the best paper on the relevance of research to the problems of peace. The papers to be submitted in the contest are to deal with this question: "To what extent is it possible to establish criteria for the delimitation of research of direct relevance to the problems of peaceful adjustment in international relations?" It will be expected that papers include attempts at theoretical as well as functional clarification of such problems as are suggested by the following questions: In what sense and under what conditions would it be possible to speak of a science of peaceful adjustment? How could such a science be integrated? To what extent would existing science fit into a similar integration? How could a science of peaceful adjustment influence actions and contribute towards changing international relations over a period of time? If several areas of research were found to be generally recognized as highly relevant to the problems of peace, would there still be any possibility of establishing criteria for the construction of priority lists for the guidance of institutions and foundations dedicated to the promotion of peace? The papers to be submitted not only will be expected to present theoretical and functional discussions of relevant criteria of this kind, but also will be expected to give concrete examples of the possible application of such criteria to problems and theories in various fields of the sciences.

Papers are to be submitted in English or French to the Institute for Social Research, Kronprinsengst. 5, Oslo, Norway, before April 1, 1952. They may be prepared by individuals, or by groups of individuals. The length of the papers is optional, but 70 to 150 double-spaced pages have been tentatively indicated as the most suitable length. To ensure anonymity of authors during the evaluation of the papers, a manuscript and a statement of authorship must be enclosed in separate envelopes, both marked with a motto chosen for the paper.

The jury which has been appointed by the Institute to judge the papers consists of Mrs. Alva Myrdal, director of the Social Science Department of UNESCO, Professor Daniel Katz of the University of Michigan, and Professor Arne Noess of the University of Oslo. The jury will be free to withhold the prize if none of the papers are found to qualify. The Institute reserves copyright, and will arrange for the publication of all of the papers which the jury considers to be of sufficient merit to be published.

The Committee on Statistics of the University of Chicago has established, under a five-year grant from the Rockefeller Foundation, a program of post- 
doctoral awards to provide training and experience in statistics for scholars whose main interests lie outside that field. Recipients of the awards must have received the doctor's degree prior to commencing the program, except in the case of recognized research workers whose experience and accomplishments are adjudged to be clearly the equivalent of the training required for the doctorate. Candidates whose mathematical preparation includes less than the usual sophomore year of calculus, or its equivalent, will not ordinarily be considered, but previous training in statistics is neither required nor expected. Candidates having under way research programs in their own fields will be preferred. Recipients of the awards must spend eleven months studying statistics at the University of Chicago, and they will be expected to enroll in a number of regular courses. There will be three awards per year, to holders of the doctorate or to persons with equivalent training and experience in the biological, the physical, and the social sciences. Each award will be $\$ 4,000$ or slightly more, and office space will be provided. In addition, $\$ 600$ to $\$ 1,000$ will be available for clerical, computational, and research assistance. There will be no tuition charges.

Applications, or requests for further information, should be addressed to the Committee on Statistics, University of Chicago, Chicago 37, Illinois. Applications for the academic year 1952-53 should be received by February 1, 1952.

The United States Office of Education, in cooperation with the Department of State, has announced the availability of fellowships to United States graduate students as provided under the Convention for the Promotion of InterAmerican Cultural Relations. Two graduate students are exchanged each year between the United States and each of the other American republics signatory to the Convention. In addition to the United States, the participating countries include: Bolivia, Brazil, Chile, Colombia, Costa Rica, Cuba, the Dominican Republic, Guatemala, Haiti, Honduras, Mexico, Nicaragua, Panama, Paraguay, Peru and Venezuela. Charges for transportation to and from the receiving country, for United States students, are paid by the United States government. The receiving government pays tuition and provides a monthly maintenance allowance. In some cases a small sum is allotted for books and incidental expenses.

The following qualifications are specified for graduate students in the United States who apply for the fellowships: United States citizenship, the bachelor's degree or its equivalent, the initiation or completion of some graduate study, a satisfactory knowledge of the language of the country in which the student wishes to study, good health, moral character, intellectual ability, and a suitable plan of study or a research topic which has been approved by the student's adviser or supervising professor. Students who desire to submit applications should write to the International Programs Branch, American Republics Section, United States Office of Education, Washington 25, D. C. Applications for fellowships for the academic year 1952-53 must be received by the Office of Education not later than January 15, 1952. 
The United Nations Technical Assistance Administration has granted a request of the Brazilian government for aid in establishing an International Center for Research and Training in Public Administration in Rio de Janeiro. A staff of five persons is being supplied by the United Nations for this project. The program includes a three-month series of seminars on the staff aspects of public administration. This series of seminars, which began November 2, will be followed in February by a one-month international seminar to which representatives of all of the other Latin-American nations will be invited. On March 1, the new training course of the Getulio Vargas Institute will begin. This course will continue through the academic year, closing at the end of November, 1952. Harvey Walker, of Ohio State University, will be a lecturer in budget formulation and execution at the Getulio Vargas Institute for the full program beginning in November, 1951, and closing in December, 1952.

The Naval War College at Newport, Rhode Island, has recently established a Chair of Military History. It is anticipated that this Chair will be filled by civilian scholars, including historians, political scientists and sociologists, as well as specialists in related disciplines. The incumbent for the first few months is Thomas Mendenhall, a historian of Yale University. An ad hoc committee, consisting of Harold Sprout of Princeton University, President James P. Baxter, III, of Williams College, and Rear Admiral Charles J. Moore, USN (Ret.), of the Brookings Institution, has been set up to review the qualifications of prospective appointees to the Chair.

W. Leon Godshall, professor of international relations at Lehigh University, was elected national president of Pi Gamma $M u$ at the eleventh annual convention of this Society, held in Washington, D. C., on June 16, 1951. He has named Eugene H. Miller, professor of political science at Ursinus College, as chancellor of the Eastern Region, and has named Benjamin H. Williams, of the Industrial College of the Armed Forces, as vice-chancellor of the Atlantic Region.

Further Data for Studying the Supply of Political Scientists. ${ }^{1}$ The United States Office of Education, in its analysis of earned degrees awarded in 1949$50,{ }^{2}$ shows a considerable increase in the total number of earned degrees awarded in all subjects as compared with the preceding year-18 per cent in bachelor's, 14 per cent in master's, and 25 per cent in doctor's degrees.

There was probably an equivalent increase in degrees awarded in political science, but the figures are not strictly comparable inasmuch as special categories were made this year of degrees awarded in public administration and international relations, which have been traditionally treated as subareas of

${ }^{1}$ For an earlier note presenting data on the supply of political scientists, see this REVIEw, Vol. 44, pp. 724-725 (Sept., 1950).

2 Robert C. Story, Earned Degrees Conferred by Higher Educational Institutions, 194950 (Federal Security Agency, Office of Education, Circular No. 282). 
political science. The following table shows degrees awarded in the three fields in 1949-50:

\begin{tabular}{|c|c|c|c|c|c|c|}
\hline & $\begin{array}{c}\text { Total } \\
\text { Bachelor's } \\
\text { Degrees }\end{array}$ & $\begin{array}{c}\text { Percentage } \\
\text { of Total } \\
\text { Bachelor's } \\
\text { Degrees }\end{array}$ & $\begin{array}{c}\text { Total } \\
\text { Master's } \\
\text { Degrees }\end{array}$ & $\begin{array}{l}\text { Percentage } \\
\text { of Total } \\
\text { Master's } \\
\text { Degrees }\end{array}$ & $\begin{array}{c}\text { Total } \\
\text { Doctor's } \\
\text { Degrees }\end{array}$ & $\begin{array}{l}\text { Percentage } \\
\text { of 'Total } \\
\text { Doctor's } \\
\text { Degrees }\end{array}$ \\
\hline \multicolumn{7}{|l|}{ Political } \\
\hline Science & 6,346 & 1.46 & 710 & 1.22 & 127 & 1.91 \\
\hline $\begin{array}{l}\text { Public Admin- } \\
\text { istration }\end{array}$ & 273 & .06 & 190 & .33 & 14 & .21 \\
\hline \multicolumn{7}{|l|}{ International } \\
\hline Relations & 981 & .23 & 279 & .48 & 25 & .38 \\
\hline Total & 7,600 & 1.75 & 1,179 & 2.03 & 166 & 2.50 \\
\hline
\end{tabular}

Whether, from the viewpoint of advocates of general education, it be regarded as "good" or "bad,"3 it is at least worth noting that, whereas public administration and international relations have customarily been regarded as fields of concentration for graduate work only, more institutions awarded bachelor's diplomas in these fields than awarded graduate degrees. In the instance of public administration, 25 institutions reported that they awarded 273 bachelor's degrees, whereas only 3 institutions gave the 14 doctorates awarded.

With the above totals as the basis for computation, political science retained in 1949-50, among the traditional seven social sciences (anthropology, economics, geography, history, political science, psychology and sociology), the same relative ranking in bachelor's degrees (fifth, again not quite as many awarded as in sociology) and in doctor's degrees (fourth, again about 30 doctorates fewer than in economics) that it had in 1947-48. In master's degrees, with the revision of categories, political science becomes third, behind history and psychology. This situation is probably explained by the fact that a master's degree in international relations or public administration is often regarded as a desirable or essential prerequisite to government service, whereas a doctor's degree in these fields is less frequently emphasized.

Forty-one institutions granted doctor's degrees in political science; about ten times as many men as women received the degree. Harvard awarded 56 of the doctorates granted during the three-year period; Chicago was second with 31 ; Georgetown and California, each with 25, Columbia with 23, and Fordham with 16, rank high. But political science seems to have less oligopoly, in so far as the awarding of doctorates is concerned, than many disciplines.

About six times as many men as women received master's degrees in political science during the three-year period.

S See the discussion of the unity of political science in Goals for Political Science (New York, 1951), pp. $52 \mathrm{ff}$. and pp. $74 \mathrm{ff}$. 
Master's and doctor's curricula in law, where the degrees awarded represent postgraduate work in jurisprudence, also contribute to the supply of political scientists. Five hundred and thirteen master's degrees (slightly less than 1 per cent of all master's degrees) and 27 doctorates (slightly more than 0.4 per cent of all doctorates) were awarded in this area. It is also clear that some economists, sociologists and historians receive what is in effect training in political science skills.

It is apparent that this type of analysis is only partially valid because of the limitations of the data. There are obvious differences in nomenclature; e.g., what is history, sociology, economics, or social science in one institution may be political science in another. A not untypical college, for instance, has recently abolished the political science concentration in favor of a general social science major with emphasis on political science. Its registrar will henceforth report more "other social science" majors and fewer majors in political science. Does this step alter in fact the supply of political scientists?

Another source of error is in inaccurate or inadequate reporting. Several slips in recording may occur between the individual student, who thinks he knows "in" what field he "majored," and the United States Office of Education. These are more likely to be errors of omission than of commission; thus our report probably underestimates the number of degrees granted in political science. One obvious area for "error," or, at any rate, for uncertainty of calculation, arises in the interpretation which registrars put upon the reports that they receive from students or departmental chairmen, or upon the failures of students and departmental chairmen to make reports.

In an effort to determine how many errors there were, the Social Science Section of the Division of Higher Education, United States Office of Education, queried 112 chairmen of departments which were not listed as giving degrees in political science. The following additions were received: A.B.'s, 138; A.M.'s, 14; and Ph.D.'s, 5. Eighty-one of the 112 institutions did not reply to this inquiry; probably some of them also awarded degrees in political science.Claude E. Hawley and Lewis A. Dexter, United States Office of Education.

Selective Service Advisory Committees. Perhaps no problem has caused more difficulty and consumed more of the time of administrators of activities in war time which require specialized personnel, than has that of the specialist under the draft. During World War II this problem became so acute that a number of extraordinary mechanisms were created to assist the Selective Service System in dealing with the problem. These included such devices as advisory committees in a number of fields, voluntary groups assisting state appeal boards, and certifying procedures instituted in federal agencies having special responsibilities for certain types of procurement of material.

In 1948 this problem arose again with the drafting of personnel for the services. It was determined jointly by the Selective Service System and the $\mathrm{Na}$ tional Security Resources Board at that time that a system of advisory committees should be set up within the Selective Service System, and that these 
committees should report directly to the director of Selective Service and be advisory to him. These committees were to be charged with the responsibility of advising the director on such policy matters as lie within the purview of the Selective Service System, and were also to advise him with regard to the disposition of cases of individuals presenting particular problems or involving difficult policy questions. Consequently, six committees were established in the engineering sciences, biological sciences, humanities (including linguistics), healing arts, physical sciences, and social sciences. When advising on general policy matters, these committees have functioned most frequently as a committee of the whole, although they do meet from time to time as individual committees when dealing with problems pertinent to their own fields of interest.

The committees have been influential in the development of national policy to a degree not anticipated when they were first established. For example the problem of student deferment now in force was developed by the committees and adopted by the Administration. They have also made numerous recommendations dealing with employment of personnel in industry and special problems of graduate education. It is probable that in the coming months, when the problems of Selective Service will become immeasurably greater because of the expected severe personnel demands of the armed services, the committees will be called upon even more than in the past.

Roscoe C. Martin, chairman of the department of political science of Syracuse University and former vice-president of the American Political Science Association, is a member of the Committee on Social Science Personnel.-M. H. Trytten, Office of Scientific Personnel, National Research Council.

\section{AN OPEN LETTER PROPOSING A SCHOOL OF CULTURAL LEGAL STUDIES}

\section{Dear Colleague:}

This letter is addressed to scholars seriously interested in the wider aspects of legal studies, and especially to those scholars in law, the humanities, and the social sciences who are sufficiently interested in the cultural study of law to be willing to spend a good deal of time and effort to promote that objective.

The plan to be described shortly was suggested by the recent transfer of The School of Letters from Kenyon College to Indiana University. The School of Letters, founded four years ago on receipt of a grant from the Rockefeller Foundation, is composed of three senior fellows, a director, and twenty-two fellows, representing different universities and colleges. Among them are many of the most distinguished literary critics in the country. They were brought together partly by a common dissatisfaction with the prevalent state of literary studies in the colleges and universities; and their cooperation was probably facilitated, despite sharp differences among them, by their sharing the view that literary criticism should be rescued from formalism and enlivened through the vivid recreation of the artists' thought. The School functioned during past summers in six-week sessions, at each of which about one-third of 
the fellows taught. Students are graduates who obtain advanced credit, auditors, and various others.

The proposal is to organize along somewhat similar lines a School of Cultural Legal Studies. Among those of you who have devoted years to the cultural study of law, whether you are "primarily" historian, political scientist, philosopher, law teacher, anthropologist, or fall in some other convenient classification, there will be many views regarding such a School. The following remarks represent my own present thoughts on the subject. They are stated somewhat categorically in order to save space- the important thing now is to get relevant ideas discussed. Obviously, the major premise of this letter is that the proposed project would require much consultation and wide cooperation of every sort.

Accordingly, without the benefit of the many suggestions which I hope will be forthcoming, I present the following tentative proposals:

1. The School of Cultural Legal Studies (or whatever it should finally be named) would have as its objective the humanistic, social-scientific study of law. It would have no vocational objectives other than the incidental training of younger or future teachers of law, social science, or the humanities (and of any new disciplines that may emerge).

2. The faculty (fellows and executive committee) of the School would consist of scholars from all the disciplines who have contributed significantly to cultural legal studies. They would represent all important viewpoints, being united in the common objective and in a willingness to collaborate, by teaching and conferences, with other scholars who have different perspectives or philosophies.

3. In addition to the regular faculty, various other scholars, some of them foreign, would be invited to teach or lecture in the sessions of the School.

4. The School would conduct summer sessions of six to nine weeks, initially, at least, at a different university each summer. The host university would provide a physical plant and library, and it might receive a portion of the fees derived from tuition.

5. It would be necessary to explore: (a) a subsidy by one of the foundations; (b) admission of students, auditors, and foreign students; (c) tuition fees; (d) fellowships; (e) faculty questions, including salaries; (f) university credit for work done and courses passed.

6. Students would be recruited from all the social sciences and humanities and from the law schools. This provision, I think, is essential because no one group could supply a sufficient number of students to make the effort worthwhile. Moreover, there are many advantages, which need not be emphasized here, in having serious students from the various disciplines work together.

7. Many possible curricula, stimulating and delightful, have stirred my imagination. With some intentional arbitrariness, I submit the following as a possible curriculum for each summer session:

(a) Three general courses

(b) Three courses on a specific subject matter 
(c) A seminar of and by the faculty, each of whom would hold forth for one week. Selected students would be invited to participate in this seminar and others permitted to attend it.

I refrain from describing the contents of the above courses and seminars so that you may feel entirely free in your thinking on this subject.

8. The executive committee, in charge of the School, should represent various viewpoints, universities, and disciplines, and its membership should be rotated. An essential need is to assure by its constituency that every qualified scholar and every scholarly viewpoint will receive fair and equal treatment. This is not easy; but it can be done!

9. A test period of at least three years would be required. If, at the end of that experimental period, the School should be continued on a secure basis, certain other matters should be explored, especially concerning (a) publication, e.g., of faculty seminar reports and teaching materials, (b) the organization of cooperative research units, (c) the carry-over of projects beyond the summer session, and (d) perhaps eventually the organization of a national research institute.

10. What is the next step to be taken at this time? This is the question regarding which I am particularly in need of help. I am willing, without any additional commitment, to serve as a temporary post office and conduit for transmitting suggestions to interested persons.

Accordingly, I invite you to write me regarding the above proposals, setting forth your views and especially your suggestions regarding organization. Do you think that the proposal is feasible? What changes and additions to the above proposals do you suggest? Are you willing to participate in the project? Have you any suggestions regarding the financing of the School? Do you think that I should ask a few persons, representing different universities and disciplines, to meet as a temporary organizing committee? Whom do you suggest should be invited to serve in that capacity? What other suggestions do you have to offer?

I have tried in this letter to avoid even the suggestion of exhortation or salesmanship. Interested scholars will, I am confident, understand the needs and opportunities adverted to, without embellishment of any kind. I should have preferred to write a personal letter to you regarding the above matters, but there are obvious advantages in the method used, not least of which is that no one who is not greatly interested in the cultural study of law will feel under any obligation to reply. I hope I have made the proposal sufficiently clear to those who are seriously interested in the indicated objectives.

\section{Indiana University.}

Sincerely,

\section{APPOINTMENTS AND STAFF CHANGES}

Byron R. Abernethy has taken a year's leave from his position as professor of government at Texas Technological College to serve as regional director of the Wage Stabilization Board, Region 10, Dallas, Texas. 